\title{
6 \\ Globalised Ireland, or, contemporary transformations of national identity?
}

\author{
G. HONOR FAGAN
}

The influential US magazine Foreign Policy issued a 'Globalization Index' in 2001, which, to the surprise of many, found the Republic of Ireland to be at the top of the list. ${ }^{1}$ The indicators used to construct the index included information technology, finance, trade, travel, 'politics' and personal communications, all designed to evaluate the degree of global integration. We learn that 'Ireland's strong pro-business policies' have made the country (or more precisely the Irish market) 'a hugely attractive location for foreign investors'. ${ }^{2}$ To make itself even more attractive, 'the country has cut corporate tax rates (already among Europe's lowest)' ${ }^{3}$ There is even better news on the financial front: while in 1996 financial inflows and outflows totalled a meagre 1.6 per cent of the national economy, by 2000 portfolio flows in Ireland were the largest in the world, in terms of gross domestic product (GDP). Those running investment funds, corporate finance, international banking and insurance companies could, with Foreign Policy, say to themselves, 'Don't Worry, Be Happy'. ${ }^{4}$ That Ireland (or at least the twenty-six counties) is doing well in terms of the index constructed by the global managers of economic internationalisation seems beyond doubt.

What is perhaps more interesting from our point of view, and leads nicely into the arguments of this chapter, is the way the globalisation index deals with (or rather does not deal with) culture. In an obscure appendix on how the index is calculated, we are told that the various indicators referred to above 'only scratch the surface of globalisation's complexity. Many other aspects of global integration - including culture defy measurement'. ${ }^{5}$ Perhaps culture cannot be measured in the same way as GDP but it is arguably a central element in the globalisation process and thus a vital element in any critical analysis of its impact. In future, it will not be good enough simply to leave out culture when dealing with globalisation or constructing indices. From an Irish 'grass roots' perspective, globalisation may not look as rosy as it does to the international financial sectors and their political supporters in Ireland. 


\section{The global}

Studies originally heralded the globalisation of communications, capital and culture, more or less in that order, and the argument was made that these forces were, in effect, decomposing the nation state and the distinctiveness of individual societies. ${ }^{6}$ This argument was followed immediately by critiques of the notion of an all-encompassing globalisation process, and the work in this mode emphasised uneven, complex and contingent aspects of globalisation. ${ }^{7}$ This chapter seeks to position itself outside either of these established approaches to the study of globalisation. Whereas, in general, the trend has been to show how global processes affect the production of single events or social change at the local or national level, I propose to reverse the trend by approaching an explanation of the global with specific reference to the national or local. Basically, I wish to ask the question 'What can a study of Ireland do for our understanding of the phenomenon called globalisation?' rather than 'How can globalisation theory explain contemporary Ireland?' In examining the specificity of Irish international and national dynamics, and the linkages between cultural and economic processes at play in 'developing' or 'imagining' Ireland, we can see tendencies and countertendencies towards a globalising dynamic.

This chapter addresses the complex articulation between the cultural and the economic in the discursive construction of Ireland in the era of globalisation. The basic argument is that, if we are to understand how Ireland has 'produced' itself in its current form, within and around the dynamics of the global forces of capitalism, then we need to examine the phenomenon of 'Ireland' through the analytical framework of cultural political economy. This should throw light on globalisation tendencies and counter-tendencies from a specific location and, likewise, show how culture implicates itself daily in the cultural political processes that have produced 'Ireland'.

The most common reading of Ireland and its current state of development is as a country that has done well in the era of globalisation, much as it had earlier done very badly in the era of imperialism. Has there really been such a turnaround? What dynamics does this debate uncover that the emerging 'global studies' approach might need to take on board? This chapter moves towards an answer in three parts: first, it examines the problematic 'placing' of Ireland in the world; second, it traces its constant (re)invention from a cultural political economy approach; and, finally, it turns to its moving parts on the global scene - its exiles and diasporas. I hope to contribute to an 'Irish' perspective on globalisation, but one that avoids the difficulties associated with taking a banal either nationalist or post-nationalist approach. 


\section{Placing}

We can usually, fairly unproblematically, 'place' a given country in the global order in terms of its economic, political or strategic importance. Yet, with Ireland, there is little agreement on 'placing'. Recently, a historian of the Americas, James Dunkerely, ${ }^{8}$ sought to place Ireland 'across the Atlantic', as it were. Dunkerely follows the tradition of 'Atlanticism" but is more sceptical of 'globalism'. However, he argues for 'the idea that Ireland is really an American country located in the wrong continent'. ${ }^{10}$ It was the Great Famine of the mid-nineteenth century and subsequent mass migrations which, supposedly, converted Ireland from an Atlantic country to an American one. This shift in cultural geography was sustained, according to Dunkerely, by a 'superabundance of myth'11 but was also validated by the one million Irish people who became US citizens in the second half of the nineteenth century. From this perspective, it is easy to leap to another end of century and an economistic reading which would 'place' Ireland as an 'outpost' of Silicon Valley. O'Hearn argues, for example, that US computer and pharmaceutical companies have set the tone for the 'Celtic Tiger', which has transformed the economic, social and cultural make-up of the country. ${ }^{12}$ Whether the economic growth of the 'Celtic Tiger' is perceived to have set the scene for the cultural transformation of Ireland, or conversely whether cultural development is thought to have set the scene for economic growth, we have here an argument that Ireland can be historically and economically placed as 'American'. Recent Irish political and social reaction to the 'terrorist' threat to the United States, on the part of conservative and radical politicians alike, seems to confirm the view of many in Ireland who see themselves as an extension, or even a part, of 'America'.

However, the 'American' perspective seems to ignore the facts of British colonial rule in Ireland and what many authors argue is a neo-colonial pattern of development in the years since independence, itself, of course, geographically incomplete. Not so long ago the question 'Is Ireland a third world country?'13 did elicit a mainly affirmative, albeit qualified, response. The colonial legacy is seen as enduring and all attempts to 'revise' Irish history beyond the nationalist myths are rejected out of hand. Thus, for example, Robbie McVeigh argues that this move to 'decolonise' (or 'postcolonise') Irish history is 'factually incorrect and intellectually dishonest' and we are enjoined 'to address the colonial legacy directly in order to transcend its negative and corrupting consequences'. ${ }^{14}$ This point may be taken simply as a truism but it does point to an apparent blind spot of the new 'postcolonial' pro-globalisation perspectives. Ireland's colonial legacy is also taken up in the literary postcolonial studies, in a more subtle way. ${ }^{15}$ The point is that the colonial legacy is inescapable in any long view of Irish history and it has had a 
range of complex effects on politics, on society and, of course, on the cultural make-up of Ireland as we know it.

Returning to the question of placing Ireland, at the economic level the Republic is certainly not simply a 'third world' (itself an anachronistic term) country. The Republic of Ireland is today one of the top performers in the European Union - the once poor and 'underdeveloped' western periphery has given way to the thriving economy and cultural revival of the 1990s, albeit with all the inequalities and problematic long-term prospects all apparently thriving economies have. In terms of the debate over whether Ireland is a 'first world' country of a US variety or a 'third world' country, I do not think we need to adjudicate between these admittedly rather starkly painted alternatives. However, I do wish to use this debate as a marker for the analysis that follows.

First, though, I wish to argue for a slightly different approach to 'global studies' than the one that dominates in the literature. It would seem that, from Malcolm Waters ${ }^{16}$ onwards, global studies, as a subject, have become parcelled out into discrete economic, political, social and cultural domains, or levels. While mindful that this may simply be a research or presentation strategy, I would be wary of going back to the old Marxist topographical analogy of 'levels'. Society is simply not a building with a structure and a 'superstructure', or roof. This type of structural determinism has long since received a decent burial and we would not really benefit from its resurrection within the new global studies. This approach is at its best when it analyses processes and flows, not bound by any determinisms and also self-consciously eschewing disciplinary boundaries. If the 'global studies' approach is to become a new paradigm in the fullest sense of the word, it will need to shake off the last vestiges of disciplinary 'ownership'. In terms of economics, there are indeed signs that Ireland is a 'satellite' of the United States, given its dependency on US companies. In terms of politics, there are indications of the same, as Irish leaders rush to support the United States in its campaign for world domination. Likewise, cultural considerations feed into both economics and politics and have to be taken into account in 'placing' Ireland. Hence my suggestion is to merge the political economy and cultural studies approaches into a new cultural political economy paradigm.

We can take up the recent call by Ngai-Ling Sum ${ }^{17}$ to create a 'cultural political economy', which is at once sensitive to cultural or discursive dynamics and the role of economic and political factors. Nigel Thrift has also referred suggestively to the 'cultural circuits of capital'. ${ }^{18}$ Thinking about 'culture' in Ireland (the 'Irish pub', Irish films, U2, Riverdance, etc.) and the new capitalism (software companies, the e-economy) has made me even more conscious of the need to build an integrated cultural political economy approach. A 'cultural' element is clearly an integral 
part of the Celtic Tiger and the 'political economy' element certainly has a strong 'cultural' component. From the critique of political economy (not its existing disciplinary forms) and from reflexive cultural studies (not an unthinking application) we may derive a critical optic which is adequate for the study of the complex reality we call 'Ireland' today. All I would add would be the need for a strongly historical approach, only sketched in here, given constraints of length, which would be necessary to make any sense of the current situation. This is, of course, a highly contested historical terrain and my rendering is not the only possible one.

\section{Inventing}

The cultural critic Declan Kiberd once wrote that 'If Ireland had never existed, the English would have invented it...' ${ }^{19}$ One could add, conversely, that because England existed, Ireland was forced to 'reinvent' itself, much as what the west knows as the 'Orient' and 'Islam' is inseparable from western discourses. It is common now to understand that nationalism is, indeed, an 'invented tradition' ${ }^{20}$ or an 'imagined community'. ${ }^{21}$ However, it would seem that in the 'era of globalisation', this approach has even greater validity for Ireland in particular. What passes for Irish 'culture' today - the musical dance show Riverdance, the 'supergroup' U2 or the ubiquitous global 'Irish pub' - does not spring from the eternal wells of the Irish soul. Rather, these phenomena are, to a large extent, manufactured by the global cultural industry. They reflect fully all of the hybridity, syncretism and even, arguably, the 'postmodernism' typical of the cultural political economy of globalisation. If globalisation can be said to have produced a 'world showcase of cultures', ${ }^{22}$ then on this stage Ireland has achieved a paradigmatic position. Ireland today, or at least Dublin, is witnessing a culture-led process of regeneration and insertion into globalisation in terms more favourable than could be expected from its economic weight.

Historically, Ireland gained its partial independence from Britain in 1921 but it was not until the Wall Street Crash of 1929 and the Great Depression of the 1930s that a consistent path of inward-oriented growth began. While De Valera's notions might today smack of right-wing romantic isolationism, his industrialisation policies did lay the basis for a more independent development strategy in Ireland. This process of conservative modernisation can be compared to the 'passive revolution' Antonio Gramsci analysed in Italy: a case of 'molecular changes which in fact progressively modify the pre-existing composition of forces and hence become the matrix of new change'. ${ }^{23}$ That new process of change occurred in the late $1950 \mathrm{~s}$, as protectionism gave way to free trade and 
inward-oriented growth turned into outward-oriented growth. As T. K. Whitaker, the architect of the post-1958 turn towards foreign loans and investments, put it at the time, 'there is really no choice for a country wishing to keep pace materially with the rest of Europe' ${ }^{24}$ So, Ireland joined the European Economic Community in 1973 and the removal of protectionism proceeded at full pace.

When Ireland 'joined' Europe in 1973, it was very much as a poor relation and major beneficiary of all the 'structural funds' made available for 'less developed' regions. It seemed that Ireland was exchanging selfreliance for dependency in a wilful shift away from the independence movement ethos. As Denis O'Hearn put it, a 'country which had virtually clothed and shod itself in 1960 imported more than seventy-one per cent of its clothing in $1980^{\prime}{ }^{25}$ This shift away from indigenous industry towards transnational investment operated across the board. It coincided with a period in which US transnational corporations (TNCs) were seeking profitable, high-tech locations, particularly ones that would offer them access to the lucrative European market. The outward-oriented growth strategy led to mass unemployment as national industries collapsed, but by the 1990s a new era of prosperity seemed to begin. Officially, the boom began in 1994, when, in an obscure European investment assessment bulletin, the US investment bank Morgan Stanley asked, perhaps tongue in cheek, whether there was a new Celtic Tiger about to join the family of East Asian tiger economies.

So, the Celtic Tiger emerged just when 'globalisation' was beginning to make itself felt in earnest. This does not mean that globalisation produced the Celtic Tiger, whose origins lay, as we saw in the bare outline above, in a series of economic transformations going back to the 1920s. And while the Irish boom may be real enough, it has its limits: growth rates are half those experienced in East Asia during the growth phase, and its sustainability is seriously in question, given the limited base of the growth sector. Dependency on the whims and market susceptibility of the transnational sector (essentially the computing and pharmaceutical sectors) is even greater than in the 1970s, insofar as in the mid-1990s this sector accounted for three-quarters of value added in manufacturing. A handful of computer companies, such as the giant processor manufacturer Intel, literally hold the key to sustained growth rates in Ireland. As the United States began to move into a slowdown by the end of 2001, if not a full-blown recession, the Celtic Tiger was beginning to look distinctly more fragile than it did a couple of years previously. Indeed, by late 2001 the Irish growth rate was officially described as 'flat'.

Going back to Ireland as a 'US' country versus Ireland as a 'third world' country, what can we now say? Ireland does seem to be very much a 'US' country, given its reliance on American investment and its often unthinking support for the United States in all matters. Yet, Ireland 
can still arguably be seen as a 'third world' country in terms of its conditions of structural dependency on the central locus of power in the era of globalisation. In the world of globalisation, there are 'globalisers' and 'globalised', and Ireland fits the latter category in political economy terms. However, Ireland is perhaps more accurately described in terms of hybridity, meaning a condition of mixed temporalities within a process of uneven development. Thus, to a large extent, cutting-edge technology coexists with traditional social relations. Luke Gibbons wrote a while back that: 'The IDA [Irish Development Authority, which helped bring in foreign investment] image of Ireland as the silicon valley of Europe may not be so far removed after all from the valley of the squinting windows', ${ }^{26}$ the latter being an image of traditional rural Ireland. This image of uneven but combined development may serve as a useful and evocative backdrop for our analysis of the cultural political economy of contemporary Ireland.

Observers of the contemporary cultural scene in Ireland are impressed by its dynamism. Conservative politician Gemma Hussey, in her book Ireland Today, refers to a 'new exuberance of self-expression which the country has never seen before' and notes the 'new Irish appetite for expression of its own identity'. ${ }^{27}$ We get a picture of a pristine and whole national identity proudly reasserting itself. Insularity is left behind as Ireland enters the world scene but remains 'in touch' with its traditions. Hussey remarks how 'Traditional music has been revived in its many forms, and enthrals tourists as much as Irish people, who are themselves, amazed by its richness'. ${ }^{28}$ From the touching tones of the travelogue, we receive an image of 'tradition' largely uncontaminated by unpleasant associations with a colonial past or a fierce anti-imperialist struggle. Faced with the 'inexorable weakening of the Irish language', which Hussey seems to see as the main repository of 'tradition', Ireland has been able to avoid 'the pressure of Anglo-American media'29 and construct for itself the eminently valuable commodity known as contemporary Irish culture.

From the left of the political spectrum we get a not dissimilar reading of Irish cultural political economy. Thus Denis O'Hearn, in his book Inside the Celtic Tiger, refers to 'Ireland's cultural revival throughout the Western world [which] was evidenced in the popularity of the musical Riverdance ${ }^{30}$ and also makes an explicit link between 'an apparently vibrant economy and a confident culture'. ${ }^{31}$ As with Hussey, the parameters of the nation state are taken for granted and one could be forgiven for thinking that globalisation was not part of the picture at all. Where the left analysis differs from the conservative one is only in its causation, because its economism leads it more or less to 'read off' the cultural transformations from the economic ones. Yet, ultimately, we get no explanation as to why Ireland has been part of 'a Pan-Celtic Revival in the years leading up to the millennium' and living in 'what amounts to little 
less than another Cultural Renaissance', ${ }^{32}$ as one radical cultural critic put it. If we are not to fall back on mystical notions of 'national culture', we must begin with the cultural political economy of globalisation in seeking an explanation.

I find it helpful to start my alternative reading with a travel story of my own. If you were to visit Ireland you might wish to travel with 'Ireland's cheap fares airline', Ryanair. If you made a telephone booking you would be politely put on hold and left listening to the rousing theme music from Riverdance, as much flamenco and Broadway as 'traditional' Irish music. From this postmodern pastiche or melange your thoughts might turn to the company itself. Ryanair is typical of the new 'hollowed out' company, whose brash chief executive, Michael O'Leary, actually is the company, and epitomises the new confident Irish entrepreneurial classes. It contrasts with the bureaucratic, more formal national carrier Aer Lingus, which still lingers in the statist era and claims massive compensation for its alleged losses following the events of 11 September 2001. But you travel Ryanair and arrive in Dublin, along with thousands of European weekend tourists keen to sample the delights of the 'fashionable' Temple Bar area. As you get to passport control there is a billboard with a leprechaun (a traditional icon of Irish folklore) and a caption that reads 'If you think this is an icon of traditional Ireland you are away with the fairies'. A small symbol in the corner of the billboard indicates this is an advertisement for ICON, which is the marketing company for the 'traditional' global Irish cream liqueur Bailey's. Can we really talk about Irish traditions anymore?

It seems clear to me that globalisation has radically redefined what we know as 'tradition'. But then tradition was always invented. It was invented in the Ireland of the 1920s, the 1960s and the 1990s. In the 1920 s, as Declan Kiberd puts it, the country engaged in 'the reconstruction of a national identity, beginning from the first principles all over again'. ${ }^{33}$ De Valera and the founders of the Irish state were in the business of constructing a modernity based on 'tradition'. To refer to 'tradition' or cultural 'authenticity' today makes little sense when we realise how pragmatic an affair the construction of a national identity is. In the 1960s, there was a reconstruction based on transnational values, first 'American' and later 'European'. Then, in the 1990s, there was another reconstruction of Irish 'identity', within global parameters. The spectacle of Riverdance, the music of the Chieftains and the 'new' Irish films cannot be understood as national cultural forms. They may be partly constituted locally but it is with reference to a global cultural market: they are local cultural keys turning global locks.

I can only conclude by rejecting any essentialist notion of 'Irishness' that is fixed from time immemorial. Neither Irish culture nor identity can be seen as self-contained, immutable or closed. A new state of flux, 
typical of postcolonialism and globalisation, opens up a new era of more fluid and uncertain constructions of cultural identity. This is also manifest at the political level, where the future of the island is, as always, uncertain. There is hardly a comfortable situation of cultural diversity being constructed where gender, ethnicity and religious conflicts become safely defused. Ireland's culture is currently showing a more threatening side. Racism around the issue of immigration and refugees highlights some of the more worrying sides of the uncertainty we now face. This is hardly the positive scenario of Gemma Hussey, for whom insularity has been replaced by 'the confidence of an outward-looking young generation'. ${ }^{34}$

\section{Moving}

The cultural critic Terry Eagleton once wrote that while, on the one hand, Ireland signifies 'roots, belonging, tradition', it also spells at the same time 'exile, diffusion, globality, diaspora ...'. ${ }^{35}$ We could posit that Ireland was always, or at least already, part of the story of globalisation, which would mean pushing back its conventional temporal origins. Being 'Irish' was always associated with movement, even while being at 'home'. Irish migration and the substantial Irish diaspora across different parts of the globe meant that 'Irishness' was, in a very real sense, a globalised identity. That was the case at the last turn of century, but now, in the 'era of globalisation', migration is not so prevalent or economically necessary. It is perhaps ironic, then, that today 'Irishness' is finding confident home-grown roots and 'home' has a certain stability to it. Irish Presidents recently (Robinson and McAleese) have foregrounded the wish to bring the diaspora 'home', culturally and politically, if not physically. The confidence of 'Irishness' on the island of Ireland today has even led to intense hostility to today's migrants created by 'globalisation' - the asylum seekers and refugees.

Movement in the nineteenth century meant dislocation, rupture and trauma in Ireland. It was associated with the Famine, the British landlord and unemployment. Emigration was, indeed, the national trauma. Today, movement means travel or working abroad or 'coming home'. The Irish media portray Ireland's citizens as the 'young Europeans', computer literate, confident, citizens of the world. Migration, then, cannot have a simple meaning as a symptom of globalisation. It can signify expulsion or, as in Ireland today, success. The diaspora was once an integral element of Irish identity. Today, there is a move to 'bring it home' but home is not what it used to be. The Ireland of today has seen the full effect of the deterritorialisation of culture. Observer Fintan O'Toole notes that 'US culture is itself in part an Irish invention' and that 'Irish culture is inconceivable without America'. ${ }^{36}$ Fluidity and hybridity have 
always been part of the Irish condition but today this occurs under the inescapable aegis of the United States, not some fuzzy, indistinct 'era of globalisation'.

Ireland was always part of broader flows of people and ideas, it was always 'globalised' and it was always a floating signifier. National 'tradition' was located as much in the diaspora as at 'home'. And 'home' today, as the accelerated movement of globalisation takes effect, is reinstated in the 'global Irish family' our politicians call the diaspora. National 'identity' is translated and appropriated by the new 'global culture'. When U2 refer to the Famine they do so in a way which makes it part of the new global history in the making. What might make an interesting analogy to extend this analysis would be John Urry's concept of sites of 'pure mobility'. ${ }^{37}$ For Urry, society is today replaced by mobility, with such icons as the airport becoming truly 'non-places'. What if Ireland were to be conceived as a place of 'pure mobility', dominated by movement and fluidity? Although only an analogy, and one that cannot be stretched too far, it may help to understand why Ireland is significant for an understanding of globalisation, too often read from the perspective of stable, settled and dominant world powers.

\section{Conclusions}

It would seem that the cultural political economy of Ireland might take us beyond the stark 'American' and 'third world' options for placing Ireland. Nor can we retreat to an essentialist notion of 'Irishness' existing since time immemorial. The cultural political economy of Ireland has never been self-contained, immutable or closed. The era of globalisation, coinciding in Ireland with that of a postcolonialism, which put the British shadow firmly behind, has created the new context for Irish development. And yet Ireland was always part of a world of flows, never static, never fixed. The elements of uncertainty and undecidability, which many see as pertaining to globalisation and/or postmodernity, have always been Ireland's lot. We cannot, in Ireland, produce 'a finished image of finished reality ${ }^{\prime 38}$ because it has always been in flux. To engage with such a society, a writer such as Roddy Doyle is necessarily 'constrained to open meaning up rather than close it down', ${ }^{39}$ as one cultural critic put it. The social and political scientist can hardly do otherwise.

At a recent International Studies Association conference, one contributor examined globalisation and the 'preservation of local identity' in Ireland.$^{40}$ Ireland was portrayed as one of those states that have 'taken advantage of the new opportunities afforded by contemporary globalisation' 41 and the conclusion was that 'The Irish have culturally escaped from a parochial sense of nationalism and become a proud member of 
the international community'. ${ }^{42}$ While certainly capturing something of what is happening in Ireland today, I think it is clear, in the light of my analysis above, why this approach is insufficient. It seems to 'buy in' totally to the ideology of globalisation: if we 'take advantage' of it we can escape 'parochial nationalism'. It was this patronising politics I sought to contest in declaring at the start that this chapter was neither nationalist nor postnationalist. Many social groups in Ireland, but many women especially, have always contested the smug conservative selfserving myths of Irish nationalism. Postnationalist accounts that imply that we have moved into a sea of tranquillity, where all conflict will be peacefully resolved in Brussels or Washington, are also problematic. The world is more complex than the 'Jihad versus McWorld'43 dichotomy, in Ireland as elsewhere, as any critical and reflexive understanding of the current world crisis would show.

An earlier version of this chapter appeared as 'Culture and globalization, placing Ireland', Annals, no. 581 (May 2002), pp. 133-43.

\section{Notes}

1 'Globalisation Index 2001', Foreign Policy (with management consultants A. T. Kearney), no. 128 (January/February 2002).

2 'Globalisation's last hurrah?', Foreign Policy, no. 128 (January/February 2002), pp. 38-51.

3 Ibid., p. 4.

4 Ibid., p. 5.

5 Ibid., p. 2.

6 For example, see K. Ohmae, The Borderless World: Power and Strategy in the Interlinked Economy (London: Collins, 1990).

7 For example, see P. Hirst and G. Thompson, Globalisation in Question (Cambridge: Polity, 1996).

8 J. Dunkerely, Americana (London: Verso, 2000).

9 Compare this usage to that of P. Gilroy, The Black Atlantic (London: Verso, 1993).

10 Dunkerely, Americana, p. xxii.

11 Ibid., p. 37.

12 D. O'Hearn, Inside the Celtic Tiger: The Irish Economy and the Asian Model (London: Pluto, 1998).

13 T. Caherty, A. Storey, M. Gavin, M. Molloy and C. Ruane (eds), Is Ireland a Third World Country? (Belfast: Beyond the Pale, 1992).

14 R. McVeigh, 'The British/Irish "peace process" and the colonial legacy', in J. Anderson and J. Goodman (eds), Dis/Agreeing Ireland (London: Pluto, 1998), p. 31.

15 For example, see P. Childs and P. Williams, An Introduction to Post-colonial Theory (London: Harverster, 1997).

16 M. Waters, Globalisation (London: Routledge, 1995).

17 N.-L. Sum, 'Globalisation and its other(s): three "new kinds of Orientalism" and political economy of trans-border identity', in C. Hay and D. Marsh 
(eds), Demystifying Globalisation (New York: Palgrave, 2000), pp. 10527.

18 N. Thrift, 'State sovereignty, globalisation and the rise of soft capitalism', in Hay and Marsh (eds), Demystifying Globalisation, pp. 71-105.

19 D. Kiberd, Inventing Ireland: The Literature of the Modern Nation (London: Jonathan Cape, 1995), p. 9.

20 E. Hobsbawn and T. Ranger (eds), The Invention of Tradition (Cambridge: Cambridge University Press, 1983).

21 B. Anderson, Imagined Communities (London: Verso, 1983).

22 M. Featherstone, Undoing Culture: Globalisation, Postmodernism and Identity (London: Sage, 1995), p. 13.

23 A. Gramsci, Selections from the Prison Notebooks (London: Lawrence and Wishart, 1971), p. 109.

24 T. K. Whitaker, 'From protection to free trade - the Irish case', Administration, 21:4 (winter 1973), p. 415.

25 O'Hearn, Inside the Celtic Tiger, pp. 41-2.

26 L. Gibbons, 'Coming out of hibernation? The myth of modernity in Irish culture', in R. Kearney (ed.), Across the Frontiers: Ireland in the 1990s (Dublin: Wolfhound Press, 1988), p. 218.

27 G. Hussey, Ireland Today: An Anatomy of a Changing State (London: Penguin, 1995), pp. 470-1.

28 Ibid., p. 484.

29 Ibid., p. 471.

30 O'Hearn, Inside the Celtic Tiger, p. 117.

31 Ibid., p. 57.

32 G. Smyth, The Novel and the Nation: Studies in the New Irish Fiction (London: Pluto, 1997), p. 175.

33 Kiberd, Inventing Ireland, p. 286.

34 Hussey, Ireland Today, p. 484.

35 T. Eagleton, 'The ideology of Irish studies', Bullan, 1 (1987), pp. 5-14.

36 F. O'Toole, The Ex-Isle of Erin: Images of a Global Ireland (Dublin: New Island Books, 1997), p. 12.

37 J. Urry, Sociology Without Society (London: Sage, 2000), p. 63.

38 Smyth, The Novel and the Nation, p. 67.

39 Ibid.

40 T. White, 'Globalisation and the preservation of local identity: the case of Ireland', paper presented at the International Studies Association conference, Hong Kong, 2001.

41 Ibid.

42 Ibid.

43 B. Barber, 'Jihad against McWorld', Atlantic Monthly, no. 269 (March 1995), pp. 53-63. 